\title{
REDUÇÃO DA JORNADA DE TRABAHO DO RESPONSÁVEL LEGAL POR PESSOA PORTADORA DE DEFICIENCIA DEPENDENTE DE TERCEIRO SEM EFEITO SALARIAL
}

\author{
Marco Aurélio Serau Junior* \\ Ágatha Priscilla Dantas Nogueira Barbosa" \\ Maria Lúcia Soares Rodrigues***
}

\begin{abstract}
RESUMO
O presente estudo objetiva analisar a situação dos trabalhadores que necessitam, além de cumprir a jornada semanal de trabalho, cuidar de Pessoas com Deficiência (PcD) que são dependentes, levando esses trabalhadores a uma jornada dupla e exaustiva e que podem ter sérios conseqüências para empregador e para a sociedade. Hoje, para os trabalhadores celetistas, somente através do judiciário é possível conseguir a redução da jornada de trabalho semanal, sem redução de salários, para acompanhamento pelo empregado de pessoa sob sua dependência que necessita de auxilio de terceiros, mas mesmo judicialmente ainda são raras as decisões favoráveis. Diante desse quadro foi proposto o projeto de Lei $\mathrm{n}^{\circ} 4.648$, de 2016, em andamento na Câmara dos Deputados para acrescentar à Consolidação das Leis do Trabalho (CLT) o artigo 58-B, que disciplina a redução da jornada de trabalho do responsável legal por pessoa com deficiência dependente de terceiros. Após a propositura do projeto houve a determinação de apensamento ao PL 6828/201, atualmente o projeto tem andamento prioritário e está aguardando a apreciação do plenário.
\end{abstract}

PALAVRAS CHAVES: Empregado, Deficiente dependente de terceiro, Redução salarial, CLT, Princípios.

${ }_{*}^{*}$ Professor da UFPR. Doutor e Mestre em D. Humanos (USP).

Possui graduação em Direito pelo Centro Universitário Salesiano São Paulo(2014). Atualmente é Advogada do Sindicato dos Trabalhadores no Comércio de Lorena - SP. Endereço currículo lattes: http://lattes.cnpq.br/3402785090073473.

**** Mestrado em Programa de Mestrado em Direito pelo Centro Universitário Salesiano São Paulo (2007). Advogada. Endereço currículo lattes: http://lattes.cnpq.br/3621242463146262. 


\begin{abstract}
The present study aims to analyze the situation of the workers who need, beyond fulfilling the work day weekly, taking care of People with Deficiency (PcD) that are dependents. Such situation takes these workers to a double and exhausting day so that it can have serious consequences for the employer and the society. Today, for the celetistas workers, it is only possible to obtain the reduction of weekly hours of working without the reduction of wages through the judiciary one for accompaniment by the employee of person under their dependence that needs third-party assistance, but even judicially still are rare the favorable decisions. In the face of this situation it was proposed the project of Law $n^{\circ} 4,648$, in the year of 2016 in progress in the House of representatives to add to the Consolidation of the Laws of Work (CLT) the article 58-B, that disciplines the reduction of working hours of the legal responsable for a person with deficiency depedent on third-party. After the bringing suit of the project had the determination of attachment to PL 6828/201, currently has priority course and, waiting the appreciation of the plenary assembly.
\end{abstract}

WORDS KEYS: Employee, Deficient dependent of third-party, wage Reduction, CLT, Principles

\title{
RESUMEN
}

El actual estudio objetivo analizar la situación de los trabajadores que necesitan, más allá de satisfacer el día del trabajo semanal, cuidar de la gente con la deficiencia (PcD) esa son dependientes. Tal situación lleva a estos trabajadores a un doble día que agota y ése pueden tener consecuencias serias para el patrón y la sociedad. Hoy, para los trabajadores celetistas, solamente con el judicial es posible obtener la reducción de las horas semanales sin reducción de los salarios para el acompañamiento del empleado de la persona bajo su dependencia que necesite ayudas del terceras, pero incluso en la cortes son todavía raras las decisiones favorables. Delante de este cuadro se ha propuesto proyecto de la Ley $n^{\circ} 4.648$, en el año de 2016 uno en marcha en la Cámara de Representantes para agregar a la Consolidación de los Leyes de Trabajo (CLT) el artículo 58-B, que disciplina la reducción de las horas de trabajo del responsables legal para la persona con la deficiencia dependiente del tercera. Después de la presentación del proyecto tuviera la determinación del apensamento para PL 6828/201, tiene actualmente con el curso e de la prioridad, esperando el aprecio de la asamblea plenaria.

LLAVES DE LAS PALABRAS: Empleado, dependiente deficiente del tercer, reducción de salario, CLT 


\section{INTRODUÇÃO}

Em nosso ordenamento jurídico há uma omissão legal quanto à redução da jornada de trabalho do responsável legal por pessoa com deficiência dependente de terceiros, sem redução salarial. Porém, está vigor no nosso ordenamento jurídico a Convenção Internacional sobre os Direitos das Pessoas com Deficiência, Decreto Lei $\mathrm{n}^{\circ}$ 6.949/09, que traz um olhar diferenciado sobre como nossa sociedade deve tratar esse agrupamento de pessoas.

Atualmente, ainda não está sendo dada devida atenção a pessoa com deficiência dependente de terceiro, embora, muito já se tenha evoluído dentro do nosso ordenamento jurídico nos últimos anos, como por exemplo, a edição da Lei de Cotas que garante ao trabalhador deficiente o direito a reserva de porcentagem de vagas na contratação, dependendo do tamanho da empresa. Posteriormente, veio a Lei Complementar 142, que regulamentou o $\$ 1^{\circ}$, do artigo 201, da Constituição Federal e permitiu ao trabalhador com deficiência uma aposentadoria com tempo de serviço reduzido dependendo do grau de sua deficiência.

Em 2015 foi editada a Lei 13.146, de 06 de junho de 2015, denominada Estatuto da Pessoa com Deficiência ${ }^{1}$ que trouxe mais garantias ao deficiente, entre elas, determina a não discriminação e sim a igualdade, garante atendimento prioritário, determina direitos a saúde, a vida a educação, a moradia, ao trabalho, a reabilitação e habilitação profissional, reforça o direito aposentadoria com redução tempo de contribuição, direito ao esporte, saúde, lazer, politico entre outros, porém, nenhuma referencia faz ao trabalhador que tem como dependente um deficiente que necessita de auxílio de terceiros.

Para o presente estudo, existirá uma comparação entre a Convenção Internacional sobre os direitos das pessoas com deficiência, a Constituição Federal, a Lei de Cotas, a Lei Complementar 142/2013, a Lei 13.146/2015 e o projeto de Lei 4.648 de 2016, com intuito de demonstrar a necessidade da aprovação do referido projeto que modifica a CLT acrescentando o artigo 58-B, durante a análise será feita uma reflexão comparada ao $\S 3^{\circ}$, do artigo

\footnotetext{
${ }^{1}$ Disponível em: <http://www.planalto.gov.br/ccivil_03/_ato20152018/2015/lei/113146.htm> Acesso em 05 de fev.2017
} 
98 da Lei 8.112/90 e a jurisprudência sobre esse último. Por fim, uma apreciação do tema no direito comparado com a legislação de Portugal, Espanha e Chile, com intuito de demonstrar que o trabalhador, que é responsável por deficiente dependente de terceiro, necessita da redução parcial de sua jornada para o tratamento dessa pessoa, sem prejuízo dos vencimentos.

\section{DESENVOLVIMENTO}

Para adentrar ao assunto é de suma importância entender o meio jurídico que a pessoa com deficiência é estabelecida, as normas que a rodeiam, e suas hierarquias, e principalmente, os princípios que as regem, resguardam e contribuem na sua inclusão, na sociedade atual.

\section{DOS PRINCÍPIOS QUE GARANTEM A PROTEÇÃO E A INCLUSÃO SOCIAL DO DEFICIENTE DEPENDENTE DE TERCEIRO}

\subsection{Da dignidade humana}

O princípio da dignidade humana preexiste ao homem embora o homem nem sempre tenha reconhecido essa característica em seu meio.

Com a inserção do princípio da dignidade humana na Carta Internacional dos Direitos Humanos e demais documentos de extrema importância no mundo jurídico, esse princípio tomou força maior passando a ser valorizado e respeitado. O principio da dignidade humana é decorrente da condição que o ser humano se encontra, sendo assim, independe de demais fatores para considerar que todos são detentores de respeito, tanto pelo Estado quanto pela a sociedade. Neste sentindo direitos e deveres são criados para garantir sua condição de existência para vida em igualdade, desta forma, o principio da dignidade humana não permanece inerte, ele cria demais princípios que afetam toda a vida social. 


\subsection{Da igualdade}

Conforme já explicitado o principio da dignidade humana pressupõem a igualdade entre os demais, trazendo esse principio para a vida em sociedade. A igualdade não é apenas um ramo do princípio da dignidade humana, mas um dos pilares para que este seja exercido em seu verdadeiro sentido. Além de ser pilar de outro principio fundamental, o princípio da igualdade possui amparo legal, conforme os termos de diversos artigo no ordenamento jurídico, principalmente o do artigo $5^{\circ}$, da Carta Magna ${ }^{2}$ “(...)todos são iguais perante a LEI(...)",_aplica-se o princípio da igualdade para buscar a criação de oportunidades iguais para todos, independente de características próprias, como raça ou condição financeira, demonstrando a relevância da palavra em seu sentido mais puro em todo o ordenamento jurídico.

\subsection{Da proteção do trabalhador}

Assim como o princípio supracitado, o legislador do Direito do Trabalho, para compensar juridicamente as assimetrias econômicas e sociais inerentes à relação de emprego, busca uma proteção maior para a parte mais frágil e economicamente menos protegida, o trabalhador.

Nesse sentido a doutrina divide o princípio protetor ou princípio da proteção em três outros sub-princípios: (i) in dúbio pro operario, (ii) norma mais favorável, (iii) condição mais benéfica, os quais abordaremos individualmente.

\subsubsection{In dúbio pro operário}

Esse subprincípio prevê quando há dúvida na interpretação da norma, a mais benéfica deve ser aplicada ao trabalhador.

\subsubsection{Norma mais favorável}

Aqui, o primado indica que quando se tem mais de uma norma aplicável, deve ser aplicada a mais favorável.

\footnotetext{
${ }^{2}$ Disponível em: <http://www.planalto.gov.br/ccivil_03/constituicao/constituicaocompilado.htm. Acesso em 05 fev.2017>
} 


\subsubsection{Condição mais benéfica}

Esse subtópico do princípio da proteção ao trabalhador consiste no direito de resistência do empregado, previsto no artigo 468 da CLT, que garante que a nova norma só será aplicada se for melhoria da condição do trabalhador.

Ressalta-se que, a proteção do trabalhador é um princípio afeto não só aos trabalhadores com capacidade laboral, mas também para aqueles que devem ter protegido o seu bem-estar, seu trabalho/habilitação e seu direito ao retorno/reabilitação.

Ainda neste princípio, podemos citar as Súmulas $\mathrm{n}^{\circ} 51$, I, e $\mathrm{n}^{\circ} 288$, I, ambas do Tribunal Superior do Trabalho, que abrangem a questão da edição de novos regulamentos empresariais (que equivalem à leis entre as partes), que venham a suprimir, revogar ou mesmo alterar direitos já conquistados e que vigem entre as partes contratantes, sendo tais alterações vedadas para os contratos em curso, incidindo o princípio da inalterabilidade contratual lesiva, plasmado no artigo 468, da CLT, o qual veda qualquer alteração contratual ainda que por mútuo consentimento entre os contratantes, que cause, de forma direta ou indireta, qualquer tipo de prejuízo ao empregado ou pessoa do trabalhador.

Súmula ${ }^{\circ} 51$ do TST

NORMA REGULAMENTAR. VANTAGENS E OPÇÃO PELO NOVO REGULAMENTO. ART. 468 DA CLT (incorporada a Orientação Jurisprudencial no 163 da SBDI-1)

I - As cláusulas regulamentares, que revoguem ou alterem vantagens deferidas anteriormente, só atingirão os trabalhadores admitidos após a revogação ou alteração do regulamento.

Súmula $\mathrm{n}^{\circ} 288$ do TST

COMPLEMENTAÇÃO DOS PROVENTOS DA APOSENTADORIA (nova redação para o item I e acrescidos os itens III e IV em decorrência do julgamento do processo TST-EED-RR-235-20.2010.5.20.0006 pelo Tribunal Pleno em 12.04.2016) Res. 207/2016, DEJT divulgado em 18, 19 e 20.04.2016

I - A complementação dos proventos de aposentadoria, instituída, regulamentada e paga diretamente pelo empregador, sem vínculo com as entidades de previdência privada fechada, é regida pelas normas em vigor na data de admissão do empregado, ressalvadas as alterações que forem mais benéficas (art. 468 da CLT). 


\subsection{Do direito fundamental ao trabalho}

O direito fundamental ao trabalho está inserido na nossa Carta Magna, em seu artigo $1^{\circ}$, IV e a valorização do trabalho humano está no artigo 170, da Constituição Federal.

Nesse princípio temos o fundamento da sustentação da dignidade humana com a garantia do trabalho que gera o sustento do obreiro e de sua família.

Com a garantia constitucional do trabalho, as normas infraconstitucionais consolidaram esse princípio

Desta forma, o direito fundamental ao trabalho deve ser observado para todos os trabalhadores pelo empregador e de forma especial para com provedor ou responsável legal por pessoa com deficiência dependente de terceiros.

\subsection{Da função social da empresa e do contrato}

A função social da empresa está prevista no artigo $5^{\circ}$, XXIII, artigo 182, parágrafo $2^{\circ}$, e artigo 186, da Constituição Federal, resumidamente podemos afirmar que, embora a finalidade de qualquer empresa seja o lucro, a função social não tem finalidade econômica. $\mathrm{O}$ papel social não está restrito ao funcionamento da empresa e sim a decisões dos administradores em prol do bem comum.

Juntamente com Estado a empresa deve gerar o bem-estar e a justiça social, denominado em inglês como "Welfare State" - $O$ Estado do Bem-estar, que é o Estado que visa o alcance dos direitos sociais, para assegurar que não exista a desigualdade. A responsabilidade social da empresa é ampla, dividindo em externa e interna. No nosso caso, interessa focar na responsabilidade social interna, principalmente, voltada ao bem-estar coletivo.

O eixo fundamental desse trabalho é a responsabilidade social para demonstrar que a empresa deve buscar o bem-estar e a qualidade de vida dos seus colaboradores, agregando valores para se tornar mais solidária para com estes na busca da justiça social.

Podemos afirmar que, com fundamento nesse princípio, cabe à empresa promover o equilíbrio social e afastar as injustiças sociais, e em consequência, no caso do empregado responsável por pessoa com deficiência dependente de terceiros é necessário uma redução da jornada 
de trabalho sem redução de salários para que o empregado tenha condições de desenvolver seu trabalho de forma digna na empresa.

\section{ESTRUTURA HIERÁRQUICA DAS NORMAS JURÍDICAS}

Conforme mencionado, tanto as súmulas como os artigos e os princípios nos levam a explanar sobre a hierarquia das normas. A principio temos uma única visão de hierarquia, a visão do jurista alemão, Hans Kelsen, algo que esta presente em todas as regras forenses, tão conhecida como "Pirâmide de Kelsen" e após grandes discussões no Supremo Tribunal ${ }^{3}$, passamos a visualizar a posição, abaixo mencionada, Controle de Convencionalidade.

A hierarquia na visão de Kelsen possui uma divisão em categorias, demonstrando que embora as normas tenham em um plano subjetivo, um único fim, as mesmas são divididas em um sistema de subordinação, uma graduação de autoridade, escaladas conforme sua importância e a forma de sua aprovação, criando uma dependência entre as normas, tendo na base da pirâmide todas as normas ordinárias e no topo a Constituição Federal.

Diante de nossa Carta Magna verificamos que a mesma estabelece a questão da hierarquia entre as normas do direito brasileiro e as oriundas do direito internacional, aplicando um sistema de aprovação para seu enquadramento na "pirâmide" hierárquica. Por outro lado, grandes doutrinadores defendem um novo tipo de controle, chamado de controle de convencionalidade, que analisaria as normas e sua aplicação, não por sistema de votação e sim uma maneira simples, com um único propósito: versar ou não sobre direitos humanos. Falar da análise da constitucionalidade à luz das normas de direito internacional do trabalho, convenções internacionais, isso seria o controle de convencionalidade.

É sabido que, a Emenda Constitucional $n^{\circ} 45^{4}$, acrescentou ao

\footnotetext{
${ }^{3} \mathrm{RE} 466.343 / \mathrm{SP}-$

http://redir.stf.jus.br/paginadorpub/paginador.jsp?docTP=AC\&docID=595444 e HC $87.585 / \mathrm{TO}$ -

http://redir.stf.jus.br/paginadorpub/paginador.jsp?docTP=AC\&docID=597891.

Acesso em 03mar2017

${ }^{4}$ PLANALTO. Disponível em:

<http://www.planalto.gov.br/ccivil_03/constituicao/Emendas/Emc/emc45.htm.

Acesso em 04 mar. 2017>
} 
artigo $5^{\circ}$, da Constituição Federal de 1988 (CF/88), um novo parágrafo, o $\$ 3^{\circ}$, que dispõem sobre a forma de aplicação e aprovação dos tratados que versam sobre Direitos Humanos. Ainda que a Emenda Constitucional não tivesse discorrido sobre a forma de aprovação, aqueles que defendem o controle de convencionalidade, já conseguem identificar se uma norma possui ou não um poder de norma constitucional e aplicação, somente pela interpretação feita ao artigo $5^{\circ}$, da $\mathrm{CF} / 88, \S 1^{\circ}$, “as normas definidoras dos direitos e garantias fundamentais têm aplicação imediata".

Os doutrinadores Valério de Oliveira Mazzuoli e Luiz Flavio Gomes, defendem a teoria do controle de convencionalidade e afirmam:

“(...) a regra que garante aplicação imediata às normas definidoras dos direitos e garantias fundamentais insculpidas no $\S 1^{\circ}$ do art. $5^{\circ}$ da Constituição sequer remotamente induz a pensar que os tratados de direitos humanos só terão tal aplicabilidade imediata (pois eles também são normas definidoras dos direitos e garantias fundamentais) depois de aprovados pelo Congresso Nacional pelo quórum estabelecido no $\S 3^{\circ}$ do art. $5^{\circ}$. Pelo contrário: a Constituição é expressa em dispor que as normas definidoras dos direitos e garantias fundamentais têm aplicação imediata, não dizendo quais são ou quais devem ser essas normas. A Constituição não especifica se elas devem provir do direito interno ou do direito internacional (por exemplo, dos tratados internacionais de direitos humanos) mencionando apenas que todas elas têm aplicação imediata, independentemente de serem ou não aprovadas por maioria qualificada $(. . .)^{5,}$

“(...) o modelo kelseniano (ou positivista legalista, ou positivista clássico) de ensino do direito "confunde a vigência com a validade da lei, a democracia formal com a substancial, não ensina a verdadeira função do juiz no Estado constitucional e garantista de Direito (que se deve posicionar como garantia dos direitos fundamentais),não desperta nenhum sentido crítico no jurista e, além de tudo, não evidencia com toda profundidade necessária o sistema de controle de constitucionalidade das leis"

5 MAZZUOLI, Valério de Oliveira. Curso de Direitos Humanos. São Paulo: Método, 2014.

${ }^{6}$ GOMES, Luiz Flávio. Estado constitucional de direito e a nova pirâmide jurídica. São Paulo: Premier Máxima, 2008. 
A posição dos doutrinadores também é defendida pelo Ministro Gilmar Mendes, que entende que os tratados de direitos humanos teriam a força de normas supralegais, ou seja, quando um tratado internacional versar sobre direitos humanos e for ratificado pelo Brasil, esse tratado entrará em nosso ordenamento jurídico hierarquicamente abaixo da Constituição Federal e acima das Leis Ordinárias, revogando assim dispositivos legais hierarquicamente inferiores, isso se não houver a aprovação prevista no artigo $5^{\circ}, \S 3^{\circ}$, da Constituição Federal que the garantisse o poder de norma constitucional, que foi alvo de grandes debates em relação ao Recurso Extraordinário no 466.343-17.

Independente da discussão, entre o entendimento doutrinário, o posicionamento jurisprudencial e as inúmeras dúvidas que a Emenda Constitucional $n^{\circ} 45 / 2004$, trouxe com a introdução do $\S 3^{\circ}$, ao artigo $5^{\circ}$, da $\mathrm{CF} / 88$, apenas um tratado internacional sobre direitos humanos teve sua aprovação no sistema inserido por essa Emenda: a Convenção sobre os Direitos das Pessoas com Deficiência e seu Protocolo Facultativo, assinado em Nova York, no dia 30 de março de 2007, conforme Decreto $\mathrm{n}^{\circ}$ 6949, de 25 de agosto de $2009^{8}$. Essa Convenção que irá reger o tema a ser discutido neste breve estudo e explanação sobre o direito da pessoa com deficiente dependente de terceiro.

\section{DAS DIVERSAS NORMAS QUE GARANTEM E BUSCAM A INCLUSÃO DO DEFICIENTE}

\subsection{Decreto legislativo $n^{0} 186$ e Decreto $n^{0}$ 6.949/2009 - inserção da convenção internacional sobre o direito das pessoas com deficiência}

Com a ratificação da Convenção sobre Direitos das Pessoas com Deficiência em $1^{\circ}$ de agosto de 2008, a norma até então de validade em âmbito internacional, começou a criar forma e poder em

\footnotetext{
${ }^{7}$ RE466.343/SP-Disponível em:

<http://redir.stf.jus.br/paginadorpub/paginador.jsp?docTP=AC\&docID=595444. Acesso em 03 mar. 2017>.

8 PLANALTO. Disponivel em: <http://www.planalto.gov.br/ccivil_03/_ato20072010/2009/decreto/d6949.htm. Acesso em 20 jan. 2017>.
} 
nosso ordenamento jurídico através do Decreto Legislativo $\mathrm{n}^{\circ} 186^{9}$, publicado em 09 de julho de 2008, pelo Congresso Nacional, após todo o procedimento previsto no $\S 3^{\circ}$, do artigo $5^{\circ}$, da $\mathrm{CF} / 88$, seguido do Decreto $\mathrm{n}^{\circ}$ 6.949, de 25 de agosto de 2009. Ambos dão a Convenção aprovada status de direito fundamental e poder de derrogar qualquer norma que esteja, ou que entenda estar, em conflito com seu teor e seja hierarquicamente inferior.

Utilizando as palavras da própria Convenção o seu escopo "é promover, proteger e assegurar o exercício pleno e equitativo de todos os direitos humanos e liberdades fundamentais por todas as pessoas com deficiência e promover o respeito pela sua dignidade inerente "10 , ou seja, trazer a pessoa com deficiência para a sociedade, dando-lhes condições mínimas para seu desenvolvimento pleno perante todas as vertentes: dignidade humana, trabalho e sociedade.

Com a inserção da Convenção versando sobre direitos das pessoas com deficiência no ordenamento pátrio, as demais normas, ainda que infraconstitucionais, surgiram e tomaram forma, assegurando os direitos desse grupo na sociedade.

Ao falar em sociedade lembramos que o meio social mais propício para uma pessoa criar personalidade e dignidade, perante a sociedade, é o meio ambiente de trabalho. Com isto passamos a analisar as diversas normas criadas, anteriores e posteriores a inserção da Convenção sobre os direitos das pessoas com deficiência, normas essas que têm o objetivo de garantir maior acesso dos deficientes ao trabalho, tais como: Lei $\mathrm{n}^{\circ} 8.213 / 1991$, Lei Complementar $n^{\circ} 142$ /2013, e a Lei $n^{\circ} 13.146 / 2015$.

\subsection{Lei $n^{\circ} 8.213 / 1991$ - Lei de cotas}

Essa lei, que entrou em vigor no dia 24 de julho de 1991, não trata especificamente sobre os direitos trabalhistas de pessoas deficientes, diverso das demais leis criadas para assegurar esse grupo

\footnotetext{
${ }^{9}$ PLANALTO. Disponível em:

<http://www.planalto.gov.br/ccivil_03/constituicao/congresso/dlg/dlg-1862008.htm. Acesso em 20 jan. 2017>

${ }^{10}$ PLANALTO. Disponível em:

<http://www.planalto.gov.br/ccivil_03/constituicao/congresso/dlg/dlg-186-

2008.htm. Acesso em 20 jan. 2017.>
} 
de pessoas, o intuito dessa legislação é garantir de vagas para deficientes e reabilitados nas empresas. A Lei $n^{\circ}$ 8.213/91, dispõe sobre os planos de benefícios da Previdência Social para todos e em seu artigo $93^{11}$, deixa uma pequena "pincelada" de dignidade para os empregados reabilitados ou com deficiência, assegurando-lhes a ocupação de cargo em empresas, conforme o número de funcionários da mesma.

Art. 93 A empresa com 100 (cem) ou mais empregados está obrigada a preencher de $2 \%$ (dois por cento) a $5 \%$ (cinco por cento) dos seus cargos com beneficiários reabilitados ou pessoas portadoras de deficiência, habilitadas, na seguinte proporção:

$\begin{array}{ll}\text { I - até } 200 \text { empregados } & 2 \% ; \\ \text { II - de } 201 \text { a } 500 & 3 \% ; \\ \text { III - de } 501 \text { a } 1.000 & 4 \% ; \\ \text { IV - de } 1.001 \text { em diante } & 5 \% \%\end{array}$

Haja vista que a lei já existe há mais de vinte e cinco anos e continua a ser cumprida de forma tímida, devida a falta de fiscalização, a participação de pessoas com deficiência foi garantida e demonstrou um passo, na verdade o primeiro passo, para a inclusão social da pessoa com deficiência. A Lei $n^{\circ}$ 8213/91 demonstrou a intenção do Estado em buscar garantir, de forma igual, princípios como a dignidade humana através da criação de mecanismos normativos que pudessem diminuir a diferença latente entre o resto da sociedade e esta parte da sociedade ainda hipossuficiente em suas garantias.

Mesmo com mecanismos normativos, o Estado não conseguiu diminuir as diversas "desculpas" por parte dos empregadores, para a falta de criação de cargos, entre elas a alegações em relação a pequena disponibilidade de empregados deficientes disponíveis no mercado de trabalho ou, até mesmo, a falta de qualificação especifica dos deficientes para ocupação das referidas cotas destinadas aos mesmos nas empresas.

\footnotetext{
${ }^{11}$ PLANALTO. Disponível em: <http://www.planalto.gov.br/ccivil_03/leis/L8213cons.htm. Acesso em 20 jan. 2017.>
} 
3.3 Lei complementar $n^{\circ} 142$ /2013 - aposentadoria da pessoa COM deficiência

Se por um lado o Estado visa a inclusão da pessoa com deficiência no mercado de trabalho utilizando uma lei de benefícios previdenciários, por outro, e ainda que não estejam no mesmo texto, o mesmo visa a concessão de aposentadoria para aqueles, que nos termos da própria lei em seu artigo $2^{\circ}$, que possuem "barreiras, podem obstruir sua participação plena e efetiva na sociedade em igualdade de condições com as demais pessoas". A Lei Complementar $n^{\circ}$ 142/2013 veio após 25 anos da promulgação da Constituição Federal, regulamentar o parágrafo primeiro do artigo 201, e para tanto utilizou-se dos mesmos termos utilizados no artigo $1^{\circ}$, da Convenção sobre Direitos das Pessoas com Deficiência, para regular as condições dessa aposentadoria: “Art. $3^{\circ}$-É assegurada a concessão de aposentadoria pelo RGPS ao segurado com deficiência, observadas as seguintes condições: (...)"

$\mathrm{O}$ Estado criou em momentos diversos essas as leis com o intuito aparente de não desamparar, primeiramente, a inclusão de pessoas com deficiência no mercado de trabalho, e em segundo plano, após o cumprimento de um prazo prefixado permitindo a retirada desse trabalhador com a jubilação. Porém, esse mesmo Estado não incentiva a diminuição das barreiras técnicas para o "real" ingresso da pessoa com deficiência no meio ambiente do trabalho com a necessária qualificação, restando refletir se o Estado realmente busca a aplicação de sua norma constitucional, como prevista no preâmbulo da Convenção Internacional, nas alíneas "f $\mathrm{f}$ " e "v"" do deficiente físico na sociedade?

“(...) f) Reconhecendo a importância dos princípios e das diretrizes de política, contidos no Programa de Ação Mundial para as Pessoas Deficientes e nas Normas sobre a Equiparação de Oportunidades para Pessoas com Deficiência, para influenciar a promoção, a formulação e a avaliação de políticas, planos, programas e ações em níveis nacional, regional e internacional para possibilitar maior

12 PLANALTO.Disponível em: <http://www.planalto.gov.br/ccivil_03/_ato20072010/2009/decreto/d6949.htm. Acessado em 20 jan. 2017.> 
igualdade de oportunidades para pessoas com deficiência, (...)

v) Reconhecendo a importância da acessibilidade aos meios físico, social, econômico e cultural, à saúde, à educação e à informação e comunicação, para possibilitar às pessoas com deficiência o pleno gozo de todos os direitos humanos e liberdades fundamentais, (...)”.

Não se esquecendo desta reflexão e analisando a Lei Complementar $n^{\circ} 142 / 2003$, podemos afirmar que foi com essa legislação que as pessoas com deficiência tiveram acesso mais digno a sua aposentadoria com a garantia legal da possibilidade de adoção de requisitos e critérios diferenciados aos segurados portadores de deficiência.

\subsection{Lei $n^{0}$ 13.146/2015 - estatuto da pessoa com deficiência}

Após verificar o incentivo ao mercado de trabalho e a garantia à aposentadoria, chegamos ao Estatuto da Pessoa com Deficiência ${ }^{13}$ que não trouxe apenas garantias em vários setores como da educação, da habitação, do trabalho, da reabilitação e da habilitação, mas inseriu na sociedade uma nova postura em relação a essas pessoas. $\mathrm{O}$ autor Lafayette Pozzoli conseguiu de maneira simples distinguir os 3 tipos de postura que a sociedade manifestava perante a pessoa com deficiência:

“(...) indiferença, caridade e paternalismo. Para o indiferente, a
pessoa com deficiência está excluída do convívio social, nega-se a
ela o substrato básico da cidadania, o 'direito de ter direitos'. Na
perspectiva do caridoso a pessoa com deficiência é um objeto, pois
tem a função de servir ao seu altruísmo, afasta-se do conceito
jurídico de 'pessoa', não sendo sequer sujeito de direitos. A postura
paternalista não permite que a pessoa com deficiência decida sobre
seus direitos e deveres, considerando-a sempre como incapaz $(. .) "$.14

13 PLANALTO. Disponível em: <http://www.planalto.gov.br/ccivil_03/_ato20152018/2015/lei/113146.htm. Acesso em 20 jan. 2017.>

14 POZZOLI, Lafayette. Pessoa portadora de deficiência e cidadania. Defesa dos direitos das pessoas portadora de deficiência. São Paulo: RT, 2006. 
Com o advento do Estatuto uma nova postura perante as pessoas deficientes foi tomada, a de paridade, tratando de forma igual aos demais e respeitando suas vontades, aplicando a essência dos já mencionados princípio da dignidade humana, da equidade. $\mathrm{O}$ Estatuto alterou as garantias e a forma com que a sociedade enxerga o deficiente, aproximando-se a um elevado grau de excelência, nos termos do Decreto ${ }^{\circ}$ 6.949/2009 ${ }^{15}$.

\section{5 lei no 8.112/1990 - a legislação do funcionário público e a possibilidade da redução da jornada de trabalho}

Encontra-se previsto no $\S 3^{\circ}$, do artigo 98, da Lei $\mathrm{n}^{\circ}$ $8.112 / 90^{16}$, que o servidor público responsável legal por pessoa com deficiência dependente de terceiro poderá exercer o direito de trabalhar em horário especial sem a necessidade de compensação de horário, vejamos:

Art. 98 in omissis

$\S 2^{2}$ Também será concedido horário especial ao servidor portador de deficiência, quando comprovada a necessidade por junta médica oficial, independentemente de compensação de horário.

$\S 3^{\circ}$ As disposições constantes do $\S 2^{\circ}$ são extensivas ao servidor que tenha cônjuge, filho ou dependente com deficiência.

Anteriormente, o servidor público tinha a obrigação legal de compensar os horários que não eram cumpridos para acompanhar seu dependente, o deficiente, porém com a redação dada pela Lei $\mathrm{n}^{\mathrm{o}} 13.370$, de $2016^{17}$, houve a dispensa da compensação o que beneficiou na realidade o deficiente que poderá ter seu responsável afastado de seu trabalho para acompanhar o seu tratamento dando dignidade ao deficiente.

Vê-se que a nova norma jurídica promoveu acentuado avanço no tratamento jurídico dado à questão.

15 PLANALTO. Disponível em: <http://www.planalto.gov.br/ccivil_03/_ato20072010/2009/decreto/d6949.htm. Acesso 20 jan. 2017.>

${ }^{16}$ PLANALTO. Disponível em:

<http://www.planalto.gov.br/ccivil_03/leis/L8112cons.htm. Acesso em 15 jan. 2017.>

${ }^{17}$ PLANALTO. Disponível em: <http://www.planalto.gov.br/ccivil_03/_ato20152018/2016/lei/L13370.htm. Acesso em 31 jan. 2017.> 


\subsection{Projeto de Lei $n^{0}$ 6.828/2013 e Projeto de Lei $n^{0}$ 4.648/2016 - a proposta inovadora}

Nesta breve análise das normas com medidas de inclusão da pessoa com deficiência conseguimos demonstrar que a legislação ainda não é totalmente eficiente e nem está ao alcance de toda população carecendo ainda de cuidados e garantias, mas se medidas estão sendo tomadas para a eficiência legal e, se essas medidas serão eficazes este é o grande questionamento, do momento.

Além da acessibilidade que a pessoa com deficiência merece ter, as condições e os direitos das pessoas que cuidam e exercem um papel fundamental para com eles até o presente momento não teve amparo legal merecido, no âmbito da CLT. Destacamos o Projeto de Lei $\mathrm{n}^{\circ}$ $6.828 / 2013^{18}$ e Projeto de Lei $\mathrm{n}^{\mathrm{o}} 4.648 / 2016^{19}$, ambos buscam a alteração da CLT para acrescentar em seu ordenamento o artigo 58-B.

O Projeto de Lei $n^{\circ} 6.828 / 2013$ visava a princípio a criação do artigo 58-B para que fosse permitido aos pais e responsáveis legais pela pessoa com deficiência, a jornada de trabalho de seis horas diárias, ou seja uma redução de duas horas diárias sobre a jornada já prevista pela lei trabalhista, sendo vedado qualquer forma de prorrogação ou compensação de tal jornada. O Projeto contava apenas com dois requisitos, a apresentação de laudo médico com a definição da deficiência do dependente e o seu grau.

A medida é amparada por leis que já preveem a importância de questões oriundas do cotidiano da pessoa com deficiência, como a lei de hierarquia constitucional, a Convenção sobre Direitos das Pessoas com Deficiência e a Lei ${ }^{\circ} 7.853 / 1989^{20}$. Mesmo que sua iniciativa fosse direcionada aos pais e responsáveis da pessoa com deficiência, que até aquele momento não tinha amparo pelos legisladores, não

\footnotetext{
${ }^{18}$ CÂMARA. Disponível

em:<http://www.camara.gov.br/proposicoesWeb/prop_mostrarintegra;jsessionid=2D FCDF595BB804E3873DECEC995BFBE3.proposicoesWebExterno1? codteor=1199 621\&filename $=P L+6828 / 2013$. Acesso em 19 dez. 2016.>

${ }^{19}$ CÂMARA. Disponível em:

<http://www.camara.gov.br/proposicoesWeb/prop_mostrarintegra?codteor=1440573 \&filename=PL+4648/2016. Acesso em 19 dez. 2016.>

20 CÂMARA. Disponível em: <http://www2.camara.leg.br/legin/fed/lei/1989/lei7853-24-outubro-1989-365493-norma-pl.html. Acesso em 10 jan. 2017.>
} 
atendia todos os requisitos necessários para que os pais e responsáveis desses deficientes pudessem de maneira digna dedicarse ao acompanhamento real de seus tutelados.

Para corrigir lacunas existentes no Projeto de Lei $n^{\circ} 6.828 / 2013$, a este foi apensado a outro Projeto de Lei $\mathrm{n}^{\circ} 4.648 / 2016$, que nas mesmas linhas de raciocínio buscava a alteração da lei trabalhista com a criação do artigo 58-B, mas desta vez com maiores facilidades para aquele que destina sua vida e responsabilidade ao deficiente com necessidade de atendimento de terceiros, com a redução não apenas de duas horas diárias de sua jornada, mas de até $25 \%$ (vinte e cinco por cento) da carga horária semanal, sem qualquer alteração salarial ou compensação das horas reduzidas da jornada. Ressaltando ainda que a redução pode ocorrer de forma diária ou em períodos, para atender a necessidade da pessoa deficiente da melhor maneira. A nova proposta contou com requisitos mais específicos e com maiores informações em relação so terceiro responsável pela pessoa com deficiência, de forma que justificaria a redução de sua jornada de trabalho para cuidar das necessidades dessas.

Enquanto o projeto de alteração e melhorias, para os pais e responsáveis de pessoas com deficiência que necessitam de ajuda de terceiros, perdura pelas casas legislativas, diversos pais que se encontram nessa situação buscam o judiciário para resolvê-la.

O Projeto de Lei $n^{\circ} 6.828 / 2013^{21}$ e Projeto de Lei $\mathrm{n}^{\mathrm{o}} 4.648 / 2016^{22}$, em andamento na Câmara Federal se assemelham ao que a Lei $n^{\circ} 8.112 / 1990$, dispõem sobre o regime aplicado aos servidores públicos, a condição de jornada especial, sem redução salarial.

Diversos foram os servidores públicos que antes da Lei

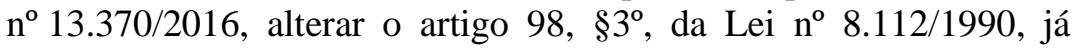
alcançaram êxito na discussão sobre a forma que seria realizada a

\footnotetext{
${ }^{21}$ CÂMARA. Disponível em:

<http://www.camara.gov.br/proposicoesWeb/prop_mostrarintegra;jsessionid=2DFC DF595BB804E3873DECEC995BFBE3.proposicoes WebExterno1? codteor=119962 1\&filename=PL+6828/2013. Acesso em 19 dez. 2016.>

${ }^{22}$ CÂMARA. Disponível em:

<http://www.camara.gov.br/proposicoesWeb/prop_mostrarintegra?codteor $=1440573$ \&filename=PL+4648/2016. Acesso em 19 dez. 2016.>
} 
compensação da jornada ou mesmo a não realização da compensação, através do auxílio jurídico. Com a alteração desse artigo essa busca passou a ser maior pelos celetistas que ainda esperam um amparo legal.

\section{A POSIÇÃO NOS TRIBUNAIS}

A previsão não permanece apenas no papel, antes que a Lei $\mathrm{n}^{\circ} 13.370 / 2016$ viesse adequar o artigo $98, \S 3^{\circ}$, da Lei $\mathrm{n}^{\circ} 8.112 / 1990$, as necessidades do cotidiano, por todo judiciário brasileiro era possível encontrar a manifestação dos tribunais, sejam eles federais, trabalhistas ou até mesmo o E. Superior Tribunal de Justiça, sobre a importância da redução de jornada de trabalho do trabalhador que necessita cuidar do deficiente dependente de terceiro, todos com decisões pautadas em princípios e garantias fundamentais.

Para os Doutos julgadores não existiam razões para aplicar a compensação de jornada nos casos em que o servidor público tivesse a obrigação e necessidade de cuidar e amparar um dependente com deficiência, como poderia zelar pelos cuidados de seu dependente e ao mesmo tempo cumprir requisitos da lei? Se assim fosse decidido, deixaria esse servidor de ter direito ao seu descanso, sobre jornada estafante com comprometimento do seu bem-estar e da sua saúde física.

Valemos então das palavras utilizadas pelo Desembargador Federal Neviton Guedes, do Tribunal Regional Federal da $1^{\circ}$ Região durante um dos seus julgamentos sobre caso semelhante:

“(...) No caso concreto, ao estabelecer um regime de proteção à pessoa com deficiência que, na verdade, deixa em condição desfavorável a criança (Lei 8.112/1990, art. 98, § $3^{\circ}$ ) em relação à pessoa já adulta (Lei 8.112/1990, art. $98, \S 2^{\circ}$ ), evidentemente, a um só tempo, o legislador investiu contra os dispositivos da Constituição e "Convenção sobre os direitos das pessoas com deficiência", ajuste internacional que ingressou, como se sabe, na ordem jurídica brasileira pelo Decreto Legislativo 186, de 9 de julho de 2008, com hierarquia de direito fundamental (artigo $5^{\circ}$, parágrafo $3^{\circ}$ da Constituição Federal), como também revelou indisfarçável incoerência interna. (...) 
(...) Na verdade, aqui, evidentemente, o legislador tira com uma mão o que pretendeu oferecer com a outra. De fato, se a mãe da criança - que deverá de qualquer sorte cumprir meia jornada de trabalho - tiver que compensar, por exemplo, à noite, ou nos finais de semanas, o horário que despendeu durante a manhã para cuidar do seu filho, não é preciso muito esforço argumentativo ou maiores habilidades lógicas para se concluir que a criança ficará, num momento (de noite) ou noutro (de manhã) sem a presença e cuidado de sua mãe.(...)".23

Após esta preciosa explanação, conseguimos visualizar os prejuízos que podem ser causados a uma família caso a lei não tivesse uma justa análise, atingindo princípios tais como: a função social do Estado, a dignidade humana, para com o responsável e com seu dependente diretamente, e a igualdade.

Não diferente foi o caminho dos servidores públicos estaduais até conseguirem a aprovação da alteração na Lei $n^{\circ}$ 8.112/90;

O caminho utilizado até a alteração da lei para funcionários públicos foi dos grandes debates nos Tribunais, tendo diversos posicionamentos até então era o caminho mais viável, vejamos diversos casos em que a redução foi permitida e outros que existia a necessidade de compensação de jornada:

EMENTA - MANDADO DE SEGURANÇA - CONCESSÃO DE REGIME DE HORÁRIO ESPECIAL, SEM PREJUÍZO DOS VENCIMENTOS - SERVIDORA, MÃE DE MENOR DIAGNOSTICADO COMO PORTADOR DE ESPECTRO AUTISTA, NECESSITADO DE CUIDADOS ESPECIAIS INEXISTÊNCIA DE LEGISLAÇÃO ESTADUAL REGULADORA DA MATÉRIA - IRRELEVÂNCIA - PRINCÍPIOS CONSTITUCIONAIS QUE DÃO SUPORTE EFETIVO PARA TUTELA DO BEM JURÍDICO MAIS IMPORTANTE, QUAL SEJA, A VIDA - ATO ADMINISTRATIVO QUE DEVE SER CONFORME A CONSTITUIÇÃO, QUE SUSTENTA AS NORMAS QUE LHE SÃO SUBORDINADAS - INTELIGÊNCIA DOS ARTIGOS 5', 196 E 227 DA CONSTITUIÇÃO FEDERAL CONVENÇÃO DA ONU SOBRE OS DIREITOS DA PESSOA

\footnotetext{
23 TRIBUNAL REGIONAL FEDERAL DA $1^{\mathrm{a}}$ REGIÃO. Agravo de Instrumento $\mathrm{n}^{\circ}$ 0051316-33.2013.4.01.0000/DF - TRF1 - Relator Desembargador Neviton Guedes.
} 
COM DEFICIÊNCIA, INCORPORADA À LEGISLAÇÃO BRASILEIRA E DISPOSITIVOS DO ECA QUE TAMBÉM AUTORIZAM O RECONHECIMENTO DO FUMUS BONI JURIS - REQUISITOS LEGAIS PARA CONCESSÃO DA MEDIDA LIMINAR, PORÉM EM MENOR ESCALA - RECURSO PARCIALMENTE PROVIDO $^{24}$.(grifo nosso)

APELAÇÃO CÍVEL. SERVIDOR PÚBLICO. LICENÇA PARA ASSISTÊNCIA A FILHO EXCEPCIONAL. REDUÇÃO DA CARGA HORÁRIA. POSSIBILIDADE.A parte autora é servidora pública estadual (professora) e ingressou com a presente ação postulando a redução de sua carga horária, para cuidar de sua filha, atualmente com 20 anos de idade, em virtude de ser portadora de Síndrome de Down e Comunicação Inter - Artrial - Cia. A prova dos autos demonstra que a filha da demandante está dependente de cuidados, necessitando da assistência direta por parte da responsável, no caso a autora. Estão presentes os requisitos do artigo 127 da Lei Estadual $n^{\circ}$ 10.098/94, pois a autora, servidora pública estadual, é responsável por excepcional físico, cabendo a concessão do benefício da redução da carga horária. - HONORÁRIOS ADVOCATÍCIOS - Verba honorária reduzida para $\mathrm{R} \$ 500,00$, levando-se em consideração os critérios do art. $20, \S 4^{\circ}$, do CPC e a jurisprudência desta Corte. REEXAME NECESSÁRIO - Nas hipóteses de sentença condenatória ilíquida proferida contra a União, o Estado, o Distrito Federal, o Município e as respectivas autarquias e fundações de direito público interno, é obrigatório o reexame necessário contemplado pelo artigo 475, § $2^{\circ}$, do Código de Processo Civil. Sentença confirmada em reexame necessário. APELO PARCIALMENTE PROVIDO (ART. $557, \S 1^{\circ}$-A, DO CPC). ${ }^{25}$ (grifo nosso)

(AG 5006157-90.2016.404.0000, Rel. MARGA INGE BARTH TESSLER, D.E. 18/05/2016). ${ }^{26}$ (grifo nosso)

24 TRIBUNAL DE JUSTIÇÃO SÃO PAULO. Disponível em: <Processo n. 2161026-17.2016.8.26.0000 - Agravo de Instrumento - 24/01/2017 do TJSP. Acesso em 02 fev. $2017>$

${ }^{25}$ TRIBUNAL DE JUSTIÇA DO RIO GRANDE DO SUL. Disponível em: <Apelação Cível No 70055840045, Terceira Câmara Cível, Tribunal de Justiça do RS, Relator: Leonel Pires Ohlweiler, Julgado em 03/11/2014). Acesso em 02 fev. 2017>

${ }^{26}$ TRIBUNAL REGIONAL FEDERAL DA $4^{\mathrm{a}}$ REGIÃO. Disponível em: <AG 5006157-90.2016.404.0000, Rel. MARGA INGE BARTH TESSLER, D.E. 18/05/2016 do TRF4. Acesso em 10 fev. 2017> 
Em dia 12 de dezembro de 2016, a mais recente alteração, ocorrida na Lei $\mathrm{n}^{\circ} 8112 / 90$, trouxe uma boa notícia para a sociedade, a luz no fim do túnel, a de que a legislação pode ser melhorada em prol dos que necessitam de cuidados especiais de seus responsáveis. Se aqueles que já detinham o direito a redução foram contemplados com melhorias, aqueles que ainda dependem da aprovação dos Projetos de Lei em andamento na Câmara Federal, supracitados, aguardam mais ansiosos pela urgente aprovação, mas certos que estão diante de uma sociedade que caminha para a excelência em aplicação dos direitos e que compreende a necessidade de medidas de inclusão para que possa ser garantida a todos uma forma de igualdade real.

A mais recente decisão que detemos conhecimento ${ }^{27}$ é o caso da redução de jornada em $50 \%$ (cinquenta por cento) da funcionária da grande PETROBRÁS. Em decisão a Juíza "a quo" do trabalho Karina Mavromati De Barros e Azevedo, concedeu de forma cautelar a concessão da redução de jornada em $50 \%$ (cinquenta por cento) sem que houvesse a redução de salário ou compensação de jornada da funcionária, que possui a necessidade de acompanhar seu filho com Síndrome de Down que faz rigoroso acompanhamento médico e precisa de cuidados diários; a mãe do menor buscou auxilio na Justiça do Trabalho da Bahia, da $5^{\circ}$ Região para que fosse possível a redução de sua carga horária para acompanhamento de seu filho.

Após a concessão de forma liminar a Juíza ratificou sua decisão em sentença se manifestando da seguinte forma:

"Impedir, negar, criar embaraços ou simplesmente impossibilitar o acesso da criança com Síndrome de Down à plenitude das possibilidades contempladas pelos tratamentos existentes para trissomia do cromossomo 21, principalmente no período compreendido entre o nascimento até os primeiros anos de vida, é fechar os olhos por completo para a citada norma constitucional e direitos que a mesma consagra, prejudicar a formação da criança como indivíduo, ou pelo menos a melhor formação possível, e contribuir para que mais uma vez direitos fundamentais fiquem em

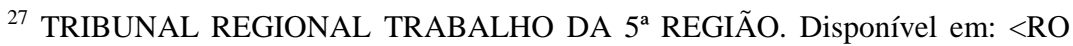
0000747-07.2016.5.05.0007, Rel. NORBERTO FRERICHS, D.E. 28/03/2017 do TRT5. Acesso em 19 abril. 2017 
segundo plano de realização ou concretização fático-material.” Juíza Karina Mavromati De Barros e Azevedo. Processo: 000074707.2016.5.05.0007 ${ }^{28}$.

Com a publicação da sentença a empresa ingressou com recurso ordinário na intenção de que a redução de jornada tivesse em contra partida a redução de salário ou que a mesma ocorresse de forma compensada. Infrutífero e ineficaz a tentativa, vez que os desembargadores da $5^{\text {a }}$ Turma, do Tribunal Regional do Trabalho da Quinta Região negaram provimento, por unanimidade, ao mérito recorrido.

DIREITOS FUNDAMENTAIS. CONCRETIZAÇÃO. FUNDAMENTOS DA SENTENÇA. Sendo a decisão baseada na busca incessante pela concretização dos direitos fundamentais como verdadeiro imperativo da dignidade da pessoa humana, respeito aos valores sociais do trabalho e construção de uma sociedade justa e solidária, atendendo ao quanto previsto em normas constitucionais, infraconstitucionais e internacionais sobre proteção à criança e pessoa com deficiência, não há que se falar que a decisão antecipatória concedida não é razoável por não haver previsão legal para tal concessão. Recurso a que se nega provimento. TRIBUNAL REGIONAL TRABALHO DA $5^{\mathrm{a}}$ REGIÃO. RO 000074707.2016.5.05.0007, Rel. NORBERTO FRERICHS, D.E. 28/03/2017 ${ }^{29}$.

Após analisar cada artigo e jurisprudência, percebemos que a caminhada é longa, que faltam ainda mecanismos legais que amparem totalmente os portadores de deficiência e seus responsáveis, sem gerar ônus para eles, independente de ser ou não servidor público, porém as pequenas noticias são atuais e demonstram que mesmo com um caminho longo a perseguir o Poder Judiciário está caminhando rumo à excelência unindo os direitos fundamentais e os princípios basilares.

28 TRIBUNAL REGIONAL TRABALHO DA $5^{\mathrm{a}}$ REGIÃO. Disponível em: <RO 0000747-07.2016.5.05.0007, Rel. NORBERTO FRERICHS, D.E. 28/03/2017 do TRT5. Acesso em 19 abril. 2017

${ }^{29}$ TRIBUNAL REGIONAL TRABALHO DA 5 $5^{\mathrm{a}}$ REGIÃO. Disponível em: <RO 0000747-07.2016.5.05.0007, Rel. NORBERTO FRERICHS, D.E. 28/03/2017 do TRT5. Acesso em 19 abril. 2017 


\section{OS DIREITOS E GARANTIAS DOS DEFICIENTES EM OUTROS PAÍSES E JURISPRUDÊNCIAS NO BRASIL}

\subsection{Legislação de Portugal}

Podemos citar como exemplo de legislação que já caminham e colhem frutos com o avanço da inclusão do deficiente, a de Portugal.

A Lei maior de Portugal, Constituição da República Portuguesa $^{30}$, estabelece em seu artigo 71 as garantias e direitos fundamentais das pessoas com deficiência:

Artigo 71 do CRP - "Cidadãos portadores de deficiência
1. Os cidadãos portadores de deficiência física ou mental gozam
plenamente dos direitos e estão sujeitos aos deveres consignados na
Constituição, com ressalva do exercício ou do cumprimento daqueles
para os quais se encontrem incapacitados.
2. O Estado obriga-se a realizar uma política nacional de prevenção e
de tratamento, reabilitação e integração dos cidadãos portadores de
deficiência e de apoio às suas famílias, a desenvolver uma pedagogia
que sensibilize a sociedade quanto aos deveres de respeito e
solidariedade para com eles e a assumir o encargo da efectiva
realização dos seus direitos, sem prejuízo dos direitos e deveres dos
pais ou tutores. 3. O Estado apoia as organizações de cidadãos portadores de deficiência."

Porém a legislação não fica restrita a sua constituição, no Código de Trabalho ${ }^{31}$ é possível encontrar medidas sociais ligadas ao meio ambiente do trabalho, não só para acesso do deficiente, mas para os terceiros, que como já mencionados, são de suma importância para o crescimento e progresso psicológico, físico e social do deficiente.

As normas garantem não só direitos aos empregados que

\footnotetext{
${ }^{30}$ Disponível em:

<http://www.parlamento.pt/Legislacao/Paginas/ConstituicaoRepublicaPortuguesa.as px. Acesso em 10 fev. 2017>

${ }^{31}$ Disponível em:<

http://www.unl.pt/data/pessoalnaodocente/Codigo_do_trabalho.pdf. Acesso em 10 fev. $2017<$
} 
possuem algum tipo de deficiência, como também cria um sistema que contempla a parentabilidade, que são medidas voltadas a todas as pessoas que exercem um papel fundamental na vida do cidadão com deficiência, seja pais ou aquele responsável legal, por exemplo, os avós, pois a legislação já garante de forma expressa esta situação.

"Art. 24. ${ }^{\circ} \mathrm{O}$ trabalhador ou candidato a emprego tem direito a igualdade de oportunidades e de tratamento no que se refere ao acesso ao emprego, à formação e promoção ou carreira profissionais e às condições de trabalho, não podendo ser privilegiado, beneficiado, prejudicado, privado de qualquer direito ou isento de qualquer dever em razão, nomeadamente, de ascendência, idade, sexo, orientação sexual, identidade de gênero, estado civil, situação familiar, situação econômica, instrução, origem ou condição social, patrimônio genético, capacidade de trabalho reduzida, deficiência, doença crônica, nacionalidade, origem étnica ou raça, território de origem, língua, religião, convicções políticas ou ideológicas e filiação sindical, devendo o Estado promover a igualdade de acesso a tais direitos.

Art. 35. ${ }^{\circ}$ Proteção na parentalidade

1 - A proteção na parentalidade concretiza-se através da atribuição dos seguintes direitos:

... in omissis

n) Licença para assistência a filho com deficiência ou doença crónica;

o) Trabalho a tempo parcial de trabalhador com responsabilidades familiares;

p) Horário flexível de trabalhador com responsabilidades familiares;

Art. $49 .^{\circ}$ Falta para assistência a filho:

1 - O trabalhador pode faltar ao trabalho para prestar assistência inadiável e imprescindível, em caso de doença ou acidente, a filho menor de 12 anos ou, independentemente da idade, a filho com deficiência ou doença crónica, até 30 dias por ano ou durante todo o período de eventual hospitalização. [...] (grifo nosso);

Art. $50 .^{\circ}$ Falta para assistência a neto ... in omissis

3 - O trabalhador pode também faltar, em substituição dos progenitores, para prestar assistência inadiável e imprescindível, em 
caso de doença ou acidente, a neto menor ou, independentemente da idade, com deficiência ou doença crónica. (grifo nosso)

Artigo $53 .^{\circ}$ Licença para assistência a filho com deficiência ou doença crônica:

1 - Os progenitores têm direito a licença por período até seis meses, prorrogável até quatro anos, para assistência de filho com deficiência ou doença crônica. ( grifo nosso)

2 - Caso o filho com deficiência ou doença crónica tenha 12 ou mais anos de idade a necessidade de assistência é confirmada por atestado médico.

3 -É aplicável à licença prevista no n. ${ }^{\circ} 1$ o regime constante dos n. 3 a 8 do artigo anterior.

4 - Constitui contraordenação grave a violação do disposto no n. ${ }^{\circ} 1$.

Artigo $54 .^{\circ}$ Redução do tempo de trabalho para assistência a filho menor com deficiência ou doença crônica

1 - Os progenitores de menor com deficiência ou doença crônica, com idade não superior a um ano, têm direito a redução de cinco horas do período normal de trabalho semanal, ou outras condições de trabalho especiais, para assistência ao filho.

... in omissis

3 - Se ambos os progenitores forem titulares do direito, a redução do período normal de trabalho pode ser utilizada por qualquer deles ou por ambos em períodos sucessivos.

4 - O empregador deve adequar o horário de trabalho resultante da redução do período normal de trabalho tendo em conta a preferência do trabalhador, sem prejuízo de exigências imperiosas do funcionamento da empresa.

5 - A redução do período normal de trabalho semanal não implica diminuição de direitos consagrados na lei, salvo quanto à retribuição, que só é devida na medida em que a redução, em cada ano, exceda o número de faltas substituíveis por perda de gozo de dias de férias. (grifo nosso)

6 - Para redução do período normal de trabalho semanal, o trabalhador deve comunicar ao empregador a sua intenção com a antecedência de 10 dias, bem como:

a) Apresentar atestado médico comprovativo da deficiência ou da doença crônica;

b) Declarar que o outro progenitor tem atividade profissional ou que está impedido ou inibido totalmente de exercer o poder paternal e, sendo caso disso, que não exerce ao mesmo tempo este direito. 
7 - Constitui contra-ordenação grave a violação do disposto nos n. 1, 3,4 ou $5 .$. ;

Art. 55..$^{\circ}$ Trabalho a tempo parcial de trabalhador com responsabilidades familiares:

1 - O trabalhador com filho menor de 12 anos ou, independentemente da idade, filho com deficiência ou doença crônica que com ele viva em comunhão de mesa e habitação tem direito a trabalhar a tempo parcial.

2 - $\mathrm{O}$ direito pode ser exercido por qualquer dos progenitores ou por ambos em períodos sucessivos, depois da licença parental complementar, em qualquer das suas modalidades.

3 - Salvo acordo em contrário, o período normal de trabalho a tempo parcial corresponde a metade do praticado a tempo completo numa situação comparável e, conforme o pedido do trabalhador, é prestado diariamente, de manhã ou de tarde, ou em três dias por semana.

4 - A prestação de trabalho a tempo parcial pode ser prorrogada até dois anos ou, no caso de terceiro filho ou mais, três anos, ou ainda, no caso de filho com deficiência ou doença crônica, quatro anos.

5 - Durante o período de trabalho em regime de tempo parcial, o trabalhador não pode exercer outra atividade incompatível com a respectiva finalidade, nomeadamente trabalho subordinado ou prestação continuada de serviços fora da sua residência habitual.

6 - A prestação de trabalho a tempo parcial cessa no termo do período para que foi concedida ou no da sua prorrogação, retomando o trabalhador a prestação de trabalho a tempo completo.

7 - O trabalhador que opte pelo trabalho em regime de tempo parcial nos termos do presente artigo não pode ser penalizado em matéria de avaliação e de progressão na carreira

8 - Constitui contra-ordenação grave a violação do disposto neste artigo.

Art. 56. ${ }^{\circ}$ Horário flexível de trabalhador com responsabilidades familiares

1 - O trabalhador com filho menor de 12 anos ou, independentemente da idade, filho com deficiência ou doença crônica que com ele viva em comunhão de mesa e habitação tem direito a trabalhar em regime de horário de trabalho flexível, podendo o direito ser exercido por qualquer dos progenitores ou por ambos.

2 - Entende-se por horário flexível aquele em que o trabalhador pode escolher, dentro de certos limites, as horas de início e termo do 
período normal de trabalho diário.

3 - O horário flexível, a elaborar pelo empregador, deve: a) Conter um ou dois períodos de presença obrigatória, com duração igual a metade do período normal de trabalho diário; b) Indicar os períodos para início e termo do trabalho normal diário, cada um com duração não inferior a um terço do período normal de trabalho diário, podendo esta duração ser reduzida na medida do necessário para que o horário se contenha dentro do período de funcionamento do estabelecimento; c) Estabelecer um período para intervalo de descanso não superior a duas horas.

4 - O trabalhador que trabalhe em regime de horário flexível pode efetuar até seis horas consecutivas de trabalho e até dez horas de trabalho em cada dia e deve cumprir o correspondente período normal de trabalho semanal, em média de cada período de quatro semanas.

5 - O trabalhador que opte pelo trabalho em regime de horário flexível, nos termos do presente artigo, não pode ser penalizado em matéria de avaliação e de progressão na carreira.

6 - Constitui contra-ordenação grave a violação do disposto no n. ${ }^{\circ} 1$.

Art. $61 .^{\circ}$ Formação para reinserção profissional $\mathrm{O}$ empregador deve facultar ao trabalhador, após a licença para assistência a filho ou para assistência a pessoa com deficiência ou doença crónica, a participação em ações de formação e atualização profissional, de modo a promover a sua plena reinserção profissional.

\subsection{Legislação da Espanha}

Prevê a legislação espanhola a redução da jornada de trabalho do empregado ou do funcionário público para cuidar de filhos ou de pessoa da família, nesse caso estendendo a mesma legislação às pessoas com deficiência. Porém, a legislação abrange de forma mais ampla o funcionário público. No caso dos empregados a previsão está nos parágrafos $1^{\circ}$ e $2^{\circ}$ do artigo 37.6 e no artigo 37.7 do Real Decreto Legislativo $2 / 15^{32}$, de 23 de outubro que aprovou a reforma do texto de Lei do Estatuto dos Trabalhadores (TRET). Já para os funcionários públicos a previsão legal está no artigo 48.h do Real

\footnotetext{
${ }^{32}$ Disponível em: <http://www.casosreales.es/BDI/legislacion/legislaciongeneral/emergentelegisla cion.php?id=1310374> Acessado em: 30 de mar. de 2017.
} 
Decreto Legislativo 5/2015, de 30 de outubro, que aprova reforma do texto de Lei do Estado Básico do Empregado Público (TREBEP), artigo 30.1.g da Lei 30/84 de 2 agosto, medidas para reforma da função pública (LMRFP) e na norma autônoma. No caso da Administração publica não pode negar o direito ao funcionário, porém há um limitador, que é quando dois empregados requerem o direito de redução da jornada na mesma Repartição, pelo mesmo motivo, pode haver uma limitação do exercício não simultâneo devido às necessidades do órgão, porém a Administração tem que justificar a limitação.

A jornada pode ser reduzida de 1/8 até a metade, porém com redução de salários, do responsável pelos menores de até 12 anos de idade, que se detenha a guarda legal, em caso doença ou que tenha uma pessoa com deficiência, ou pessoa da família de até segundo grau que dependa do empregado e não tenha atividade remunerada. A redução da jornada terá que ser diária, não podendo concentrar a redução em um dia da semana com isso facilita a gestão dos recursos humanos das empresas ou das administrações públicas.

Percebe-se que a lei espanhola observou que conciliar a vida familiar e laboral possui uma dimensão maior que leis trabalhistas, possuem dimensão constitucional a ponto de que a conciliação entre as duas deve prevalecer e sempre servir de orientação quando existir conflitos.

Pode usufruir desse direito todos os trabalhadores, homens ou mulheres em jornada integral ou parcial, inclusive os temporários. $\mathrm{O}$ intuito da norma é facilitar a conciliação do trabalho com os cuidados e responsabilidade familiar.

\subsection{Legislação do Chile}

Ao buscar e estudar a legislação do Chile é possível verificar que houve uma evolução legislativa em relação à desigualdade de gênero, a diferença entre homens e mulheres, mas em relação a inclusão e dignidade dos portadores de deficiência ainda existe muito a ser realizado, principalmente em reformas na politica e na lei chilena, para que o país honre com todos acordos internacionais aderidos, incidindo em mudanças significativas para conciliar família e trabalho, como verificamos na lei espanhola. 
Os maiores apoios jurídicos aos direitos desse agrupamento vem através da Convenção sobre os direitos das pessoas com Incapacidade datada de dezembro de 2006 e ratificada pelo Chile em agosto de 2008, a OIT $n^{\circ} 159$ e pela Lei $n^{\circ} 20.422$, em seus artigos 43 a 47, que buscam a igualdade de oportunidades e inclusão social das pessoas com incapacidade, porém em relação a oportunidade das pessoas que possuem deficientes na família e que necessitam de auxilio para o bemestar dos entes ainda não existe de forma significativa.

A busca pela igualdade de gêneros esta constitucionalmente reconhecida pela Lei ${ }^{\circ} 19.611$, de 16 de junho de $1999^{33}$, em que houve a substituição da expressão utilizada na Constituição chilena "los hombres" por "las personas", tornando a lei ampla para os deveres e direitos dos indivíduos, causando também um reflexo em todo o Código de Trabalho.

No que diz respeito a "ausentar-se para cuidar da família" a lei trabalhista chilena prevê em seu artigo $199^{34}$ a possibilidade de mães ou pais se ausentarem do serviço para cuidar do filho, quando este tiver menos que um ano de idade e que possua alguma doença grave ou que esteja com risco de morte; porém mesmo que a lei seja para os pais e mães, o pai apenas poderá gozar desse beneficio se ambos os genitores trabalharem fora e a mãe, caso seja de seu interesse, poderá deixar de usufruir desse direito em prol do pai, ou ainda poerá exercer esse direito se a mãe do menor for falecida, com a guarda do menor para o pai judicialmente. Também o artigo 199 prevê uma permissão de ausência quando o filho for menor de 18 anos e dependa de cuidados por acidente grave ou doença que já esteja em fase terminal, podendo se ausentar no máximo ao número de horas equivalente a 10 jornadas completas de trabalho. Tal aplicação demonstra que a lei foi alterada e colocou homens e mulheres em patamares iguais, porém as demais leis demonstram que a obrigação de cuidar dos filhos ainda é, apenas, da mulher, criando mais uma barreira para os cuidados com os dependentes pelo pai, engessando a lei trabalhista.

33 Disponível em: <http://www.leychile.cl/Navegar?idNorma=137783>.Acessado em: 06 de abr. de 2017.

${ }^{34}$ Dísponivel em: < https://www.leychile.cl/Navegar?idNorma=207436\&idParte=0> Acessado em: 04 de abr. de 2017. 
Embora não exista uma previsão legal robusta para o responsável pela pessoa com deficiência dependente de terceiro de uma redução de jornada, percebe-se que existe uma necessidade maior na evolução de toda legislação no que se refere as pessoas com deficiência, pode-se afirmar que já existe uma preocupação com a inclusão social e que provavelmente evoluirá para atender a todos com dignidade, todavia com a legislação em vigor, percebe-se que a inclusão laboral no Chile é possível, porém depende de inúmeras boas práticas, tanto de empresas públicas como privadas, com o apoio do Estado na politica e na legislação, alcançando da mesma forma que foi realizado com a busca de igualdade de gênero para a inclusão das pessoas com alguma deficiência alcançando também aqueles que são fundamentais para seu bem-estar.

\section{CONCLUSÃO}

O trabalhador celetista necessita que o ordenamento jurídico do país crie uma normatização para regularizar a situação laboral dos pais ou responsáveis legais por pessoas portadoras deficiência uma redução significativa na jornada diária ou semanal, sem a redução salarial para que possam desenvolver as atividades necessárias ao pleno desenvolvimento desse agrupamento com inserção na sociedade de forma digna, como já acontece com os servidores públicos federais que são pais ou responsáveis por pessoa com deficiência dependente de terceiros.

Atingir o objetivo constante da Convenção, ratificada pelo Brasil, sobre os direitos das pessoas com deficiência promovendo, protegendo e assegurando o exercício pleno e equitativo de todos os direitos exige ações governamentais que permitam, aos pais e responsáveis, um acompanhamento digno das pessoas portadoras de deficiência, independente do cumprimento da jornada diária ou semanal de trabalho. A dignidade vai além do simples acompanhamento, ela exige a possibilidade de garantir condições mínimas para o desenvolvimento pleno das pessoas deficientes dependentes desses trabalhadores.

A sociedade num sentido amplo tem que criar condições para que o responsável pelas pessoas deficientes dependentes de terceiros tenham os salários garantidos na integralidade e horários disponíveis 
para acompanhar o atendimento necessário e tratamento digno com respeito que necessita esse agrupamento.

Os Projetos de Lei $n^{\circ}$ 6828/13 e no 4.648/16 que alteram a CLT acrescentando o artigo 58-B buscam atender a necessidade dos empregados celetistas, pais ou responsáveis por pessoas com deficiência dependente de terceiros, trazendo uma realidade necessária ao nosso ordenamento jurídico.

Exemplos em legislação de outros países que conseguiram regularizar a difícil situação desses trabalhadores responsáveis por pessoas deficientes dependentes de terceiros, como por exemplo Portugal e Espanha, nos mostra que estamos no caminho certo.

O próprio ordenamento jurídico pátrio que trouxe alterações a Lei $n^{\circ} 8.112 / 90$, favorecendo aos funcionários públicos tem que servir de norte para contemplar também os trabalhadores celetistas, evitando que esses últimos sejam obrigados a buscar a aplicação por analogia da legislação aplicada ao servidor que sobrecarregaria em muito o judiciário brasileiro que já tem um excesso de demandas.

Se a sociedade se unir e buscar a normatização mais justa para esses trabalhadores que em seu seio familiar possuam pessoas deficientes dependentes de terceiros, em prol da aprovação da inclusão do artigo 58-B na CLT, com certeza permitirá ao trabalhador a manutenção de seu salário, com uma redução de sua jornada, e sem redução de salários, com a finalidade de promover o atendimento às necessidades de seus tutelados.

Esse movimento, que visa concretizar direitos fundamentais ao mesmo tempo dos trabalhadores e das pessoas com deficiência encontra, porém, profunda dificuldade.

Dificuldade em virtude do projeto neoliberal que volta a florescer no país, notadamente a partir do julgamento do impeachment da Presidente Dilma Roussef. Dificuldade e resistência decorrentes do processo de precarização das relações de trabalho que é levado a curso a partir do Projeto de Lei 6.787/2016, o qual busca promover profunda reformulação (paradigmática) do Direito do Trabalho.

A proposta de uma "nova CLT", mais do que alterar cerca de 200 (duzentos) artigos daquela Consolidação, imprime verdadeira subversão do conteúdo tradicional de proteção ao trabalhador. No que concerne ao objeto deste trabalho, a dificuldade específica é o 
agravamento da jornada laboral, que se dá pela minoração do pagamento de horas extras, ampliação do sistema de banco de horas e exasperação da metodologia de contratos de trabalho de tempo intermitente, todos altamente prejudiciais aos trabalhadores.

Que esse cenário, contudo, não represente barreira para a defesa dos direitos dos trabalhadores e a consagração da dignidade das pessoas com deficiência, na esteira do que preconizado aqui, a extensão da jornada de trabalho reduzida para os trabalhadores que também exercem a função de cuidadores de pessoas com deficiência.

\section{BIBLIOGRAFIA}

BRASIL. Constituição Federal do Brasil(1988). Brasília: Senado Federal, Subsecretaria de Edições Técnicas, 2013. 448p.

. Decreto n. 6.949, de 25 de agosto de 2009. Promulga a Convenção Internacional sobre os Direitos das Pessoas com Deficiência e seu Protocolo Facultativo, assinados em Nova York, em 30 de março de 2007.

Lei n. 7.853, de 24 de outubro de 1989. Dispõe sobre o apoio às pessoas portadoras de deficiência, sua integração social, sobre a Coordenadoria Nacional para Integração da Pessoa Portadora de Deficiência - Corde institui a tutela jurisdicional de interesses coletivos ou difusos dessas pessoas, disciplina a atuação do Ministério Público, define crimes, e dá outras providências.

Lei n. 8.112, de 11 de dezembro de1990. Dispõe sobre o regime jurídico dos servidores públicos civis da União, das autarquias e das fundações públicas federais..

Lei n. 8.213, de 24 de julho de 1991. Dispõe sobre os Planos de Benefícios da Previdência Social e dá outras providências.

Lei Complementar n. 142 de 8 de maio de 2013. Regulamenta o $\S 1^{\circ}$ do art. 201 da Constituição Federal(1988), no tocante à aposentadoria da pessoa com deficiência segurada do Regime Geral de Previdência Social - RGPS.

Lei n. 13.146, de 6 de julho de 2015. Institui a Lei Brasileira de Inclusão da Pessoa com Deficiência (Estatuto da Pessoa com Deficiência).

Câmara dos Deputados. Projetos de Lei e Outras Proposições.

Ementa. Acrescenta artigo à Consolidação das Leis do Trabalho, aprovada 
pelo Decreto-lei ${ }^{\circ} 5.452$, de $1^{\circ}$ de maio de 1943, para disciplinar a redução da jornada de trabalho do responsável legal por pessoa com deficiência dependente de terceiros, nas condições que especifica. <http://www.camara.gov.br/proposicoesWeb/fichadetramitacao?idProposic $\mathrm{ao}=2078960>$.

Disponível

Câmara dos Deputados. Projetos de Lei e Outras Proposições. em:<http://www.camara.gov.br/proposicoesWeb/prop_mostrarintegra;jsessi onid=2DFCDF595BB804E3873DECEC995BFBE3. proposicoesWebExtern o1 ? codteor $=1199621 \&$ filename $=P L+6828 / 2013$.

Disponível

Câmara dos Deputados. Projetos de Lei e Outras Proposições. http://www.camara.gov.br/proposicoesWeb/prop_mostrarintegra?codteor=1 440573\&filename=PL+4648/2016.>

Disponível

Câmara dos Deputados. Projetos de Lei e Outras Proposições. http://www.camara.gov.br/proposicoesWeb/prop_mostrarintegra;jsessionid =2DFCDF595BB804E3873DECEC995BFBE3. proposicoesWebExterno1?c odteor $=1199621 \&$ filename $=P L+6828 / 201>$

Disponível

Câmara dos Deputados. Projetos de Lei e Outras Proposições. "http://www.camara.gov.br/proposicoesWeb/prop_mostrarintegra?codteor= 1440573\&filename $=\mathrm{PL}+4648 / 2016 .>$

. Supremo Tribunal Federal. Recurso Extraordinário 466.343-1, Relator Min. Cezar Peluzo, Voto-vogal do Min. Gilmar Mendes.Recorrente: Banco Bradesco S/A. Recorrido: Luciano Cardoso Santos.

. Tribunal Regional Federal da $1^{\mathrm{a}}$ Região. Agravo de Instrumento $\mathbf{n}^{0}$ 0051316-33.2013.4.01.0000/DF - TRF1 -Relator Desembargador Neviton Guedes

. Tribunal Regional Federal da $4^{a}$ Região. Agravo de Instrumento: AG 50401433520164040000 5040143-35.2016.404.0000. Relator: Vivian Josete Pantaleão Caminha.

. Tribunal Regional Federal da $4^{a}$ Região. Agravo de Instrumento. Disponível em: <AG 5006157-90.2016.404.0000, Rel. MARGA INGE BARTH TESSLER, D.E. 18/05/2016 do TRF4.

. Tribunal Regional Trabalho da $5^{\mathrm{a}}$ Região. Recurso Ordinário. Disponível em: <RO 0000747-07.2016.5.05.0007, Rel. NORBERTO FRERICHS, D.E. 28/03/2017 do TRT5. 
CÁRDENAS, Leonardo Castillo. SCHWARTZMAN, Saracostti Mahia. BALLESTEROS, Tapia Patricia. "Balance entre familia y trabajo: un análisis comparativo de Chile y España desde una Normativa Internacional hacia Regulaciones Laborales" - Revista "Lus et Praxis" Universidade de Talca - Faculdade de Ciências Juridicas e Sociais, ano 22, n 1, 2016, pág. $493-524$.

CASOSREALES, sítio espanhol. Disponível em: $<$ http://www.casosreales.es/BDI/legislacion/legislaciongeneral/emergentele gislacion.php?id=1310374>

CHILE, Constituição Politica da Republica do Chile. Disponível em: <https://www.leychile.cl/Navegar?idNorma=242302> Acessado em: 30 de mar. de 2017.

CHILE. Ley Chile. sítio chileno. Disponível em: < http://www.leychile.cl/Navegar?idNorma=137783>.Acessado em: 06 de abr. de 2017.

CHILE. Ley Chile, sítio chileno. Disponível em: $<$ https://www.leychile.cl/Navegar?idNorma=207436\&idParte=0> Acessado em: 04 de abr. de 2017.

CLÈVE, Clèmerson Merlin (Coord.). Direito Constitucional Brasileiro: Teoria da Constituição e Direitos Fundamentais. $1^{a}$. Ed. São Paulo: Revista dos Tribunais, 2014. v. 1.1165 p.

CUIMENTI, Ricardo C.; CAPEZ, Fernando; ROSA, Marcio F. E.; SANTOS, Marisa F. Curso de Direito Constitucional. $3^{\text {a }}$ ed. São Paulo: Saraiva, 2006. 608 p.

DOWN, Federação Brasileira das Associações Síndrome de. Lei das Cotas de Deficientes. Disponível em: $<$ http://www.federacaodown.org.br/site/index.php/noticias/466-lei-dascotas-de-deficientes.html> Acesso em: 06/02/2017.

DURÁN, Carolina Gala. Estudios de Relaciones Laborales: La reducción de la jornada y la excedencia por cuidado de hijos e familiares em las administraciones públicas. Vol. 9. Gabinete de Prensa y Comunicación de la Diputación de Barcelona. Barcelona: Marzo 2016. 136 p.

FIUZA, César Augusto de Castro. NETO, Orlando Celso da Silva. JUNIOR, Otavio Luiz Rodrigues. XXIV CONGRESSO NACIONAL DO CONPEDI - UFMG/FUMEC/DOM HELDER CÂMARA. DIREITO CIVIL CONTEMPORÂNEO II. CONPEDI, 2015.

GOMES, Luiz Flavio. Controle de Convencionalidade. Valério Mazzuoli. Disponível

em: 
<http://www.migalhas.com.br/dePeso/16,MI87878,91041Controle+de+Con vencionalidade+Valerio+Mazzuoli+versus+STF> Acessado em: 06/02/2017.

GUERRA, Sidney. Direito Internacional dos Direitos Humanos. $2^{\mathrm{a}}$ ed. São Paulo: Saraiva, 2015. 239p.

LEITE, George S. (Coord.). Dos Princípios Constitucionais: Considerações em torno das normas principiológicas da Constituição. 2a . Ed. rev., atualiz., ampl. São Paulo: Método, 2008. 415 p.

LEITE, Carlos Henrique Bezerra. Manual de Direitos Humanos. $3^{\mathrm{a}}$. ed. São Paulo: Atlas, 2014. 182 p.

MARMELSTEIN, George. Curso de Diretos Fundamentais. $3^{\text {a }}$ ed. São Paulo: Atlas, 2011. 591 p.

MAZZUOLI, Valério de Oliveira. Curso de Direitos Humanos. São Paulo: Método, 2014. p. 199.

MORAES, Alexandre de. Direito Constitucional. $17^{\mathrm{a}}$ ed. atual. São Paulo: Atlas, 2005. $918 \mathrm{p}$.

PORTUGAL. Constituição da República Portuguesa, de 25 de abril de 1974.

em:

$<$ http://www.parlamento.pt/Legislacao/Paginas/ConstituicaoRepublicaPortu guesa.aspx>. Acesso em: 06/02/2017.

PORTUGAL. Código do Trabalho - Versão Atualizada, agosto de 2016. Disponível em:

http://www.cite.gov.pt/asstscite/downloads/legislacao/CT25082016.pdf> Acesso em: 07/02/2016.

POZZOLI, Lafayette. Pessoa portadora de deficiência e cidadania. Defesa dos direitos das pessoas portadora de deficiência. Luiz Alberto David de Araujo (coord.). São Paulo: RT, 2006, p. 182-195.

RAMPAZZO. Lino. Metodologia Cientifica. 4a . ed. São Paulo: Loyola, 2009.146 p.

RIO GRANDE DO SUL (ESTADO). Tribunal de Justiça do Rio Grande Do Sul. Apelação Cível. Disponível em: <Apelação Cível No 70055840045, Terceira Câmara Cível, Tribunal de Justiça do RS, Relator: Leonel Pires Ohlweiler, Julgado em 03/11/2014)

SÃO PAUlO (ESTADO). Tribunal de Justiça de São Paulo.Agravo de Instrumento. Disponível em: <Processo n. 2161026-17.2016.8.26.0000 Agravo de Instrumento - 24/01/2017 do TJSP. 
